\title{
Challenges in the Synthesis of Active Site Mimics for [NiFe]- Hydrogenases
}

\author{
Debashis Basu, ${ }^{a}$ Danielle L. Gray, ${ }^{a}$ Toby J. Woods, ${ }^{a}$ and Thomas B. Rauchfuss ${ }^{* a}$ \\ aSchool of Chemical Sciences \\ University of Illinois \\ Urbana, IL 61801, USA
}

Federica Arrigonib and Giuseppe Zampella*b

bepartment of Biotechnology and Biosciences

University of Milano-Bicocca

Piazza della Scienza 2

20126-Milan, Italy

Figure S1. ${ }^{1} \mathrm{H}-\mathrm{NMR}$ spectrum of $\mathrm{Ni}\left(\mathrm{N} 2 \mathrm{~S}^{555}\right)$ in $\mathrm{CD}_{3} \mathrm{CN}$ solution

Figure S2. ${ }^{31} \mathrm{P}-\mathrm{NMR}$ spectrum of $\mathrm{NiCl}_{2}(\mathrm{dppv})$ in $\mathrm{CH}_{2} \mathrm{Cl}_{2}$ solution

Figure S3. ${ }^{31} \mathrm{P}-\mathrm{NMR}$ spectra for the reaction of $\mathrm{Ni}\left(\mathrm{N} 2 \mathrm{~S}^{255}\right)$ and $\mathrm{NiCl}_{2}(\mathrm{dppv})$ in $\mathrm{MeCN}$ solution. Top: $2 \mathrm{~h}$ ( $15 \%$ conversion). Middle: $12 \mathrm{~h}$ (67\% conversion). Bottom: $36 \mathrm{~h}$ ( $80 \%$ conversion).

Figure S4. ${ }^{31} \mathrm{P}-\mathrm{NMR}$ spectrum of product(s) of the reaction of $\mathrm{Ni}\left(\mathrm{N} 2 \mathrm{~S} 2{ }^{555}\right)$ and $\mathrm{NiCl}_{2}$ (dppv) in acetone solution after $10 \mathrm{~h}(\sim 80 \%$ conversion). S6

Figure S5. ${ }^{31} \mathrm{P}-\mathrm{NMR}$ spectrum of crude $\left\{\mathrm{Ni}(\mathrm{Cl})(\mathrm{dppv})\left[\mathrm{Ni}\left(\mathrm{N} 2 \mathrm{~S}^{555}\right)\right]\right\} \mathrm{BF}_{4}$ in $\mathrm{CDCl}_{3}$ solution.

Figure S6. ${ }^{1} \mathrm{H}-\mathrm{NMR}$ spectrum of crude $\left\{\mathrm{Ni}(\mathrm{Cl})(\mathrm{dppv})\left[\mathrm{Ni}\left(\mathrm{N}_{2} \mathrm{~S}^{555}\right)\right]\right\} \mathrm{BF}_{4}$ in $\mathrm{CDCl}_{3}$ solution.

Figure S7. ESI-MS (positive mode) of $\left\{\mathrm{Ni}(\mathrm{Cl})(\mathrm{dppv})\left[\mathrm{Ni}\left(\mathrm{N}_{2} \mathrm{~S}^{555}\right)\right]\right\} \mathrm{BF}_{4}$ in $\mathrm{MeCN}$ solution.

Figure S8. Elemental composition report for ESI-MS in positive mode for $\left\{\mathrm{Ni}(\mathrm{Cl})(\mathrm{dppv})\left[\mathrm{Ni}\left(\mathrm{N} 2 \mathrm{~S}^{555}\right)\right]\right\} \mathrm{BF}_{4}$ in $\mathrm{MeCN}$ solution. S10

Figure S9. ${ }^{31} \mathrm{P}-\mathrm{NMR}$ spectrum (expanded) of $\left\{\mathrm{Ni}(\mathrm{Cl})(\mathrm{dppv})\left[\mathrm{Ni}\left(\mathrm{N} 2 \mathrm{~S}^{555}\right)\right]\right\} \mathrm{BF}_{4}$ in $\mathrm{CDCl}_{3}$ solution. The sample was prepared from the batch of crystals analyzed by X-ray crystallography.

Figure S10. ${ }^{1} \mathrm{H}-\mathrm{NMR}$ spectrum of $\left\{\mathrm{Ni}(\mathrm{Cl})(\mathrm{dppv})\left[\mathrm{Ni}\left(\mathrm{N} 2 \mathrm{~S}^{555}\right)\right]\right\} \mathrm{BF}_{4}$ in $\mathrm{CDCl}_{3}$ solution. The sample was prepared from the batch of crystals analyzed by X-ray crystallography.

Figure S11. ${ }^{31} \mathrm{P}-\mathrm{NMR}$ spectra of the reaction of $\left\{\mathrm{Ni}(\mathrm{Cl})(\mathrm{dppv})\left[\mathrm{Ni}\left(\mathrm{N} 2 \mathrm{~S}^{555}\right)\right]\right\} \mathrm{BF} 4$ and $\mathrm{AgBF}_{4}$ in MeCN solution. Top: 30 min. ( $\sim 87 \%$ desired complex). Middle: $3 \mathrm{~h}$ (68 \% desired complex). Bottom: expanded high field region.

Figure S12. ${ }^{31} \mathrm{P}-\mathrm{NMR}$ spectrum of the product mixture from the reaction of $\mathrm{NiCl}_{2}(\mathrm{dppv})$ and $\mathrm{Ni}\left(\mathrm{N} 2 \mathrm{~S}^{555}\right)$ in $\mathrm{CD}_{3} \mathrm{COCD}_{3}$ solution.

Figure S13. ${ }^{31} \mathrm{P}-\mathrm{NMR}$ spectrum of $\left[\mathrm{Ag}(\mathrm{dppv})_{2}\right] \mathrm{BF}_{4}$ in $\mathrm{MeCN}$ solution. S15 Figure S14. ${ }^{31} \mathrm{P}-\mathrm{NMR}$ spectrum of $\left\{\mathrm{Ni}(\mathrm{dppv})\left[\mathrm{Ni}\left(\mathrm{N} 2 \mathrm{~S}^{555}\right)\right]\right\}\left(\mathrm{BF}_{4}\right)_{2}$ in $\mathrm{CD}_{3} \mathrm{COCD}_{3}$ solution. Sample was prepared from the batch of crystals grown for X-ray crystallography. .....S16 
Figure S15. ${ }^{1} \mathrm{H}-\mathrm{NMR}$ spectrum of the $\left\{\mathrm{Ni}(\mathrm{dppv})\left[\mathrm{Ni}\left(\mathrm{N} 2 \mathrm{~S}^{555}\right)\right]\right\}\left(\mathrm{BF}_{4}\right)_{2}$ in $\mathrm{CD}_{3} \mathrm{COCD}_{3}$ solution. Sample was prepared from the batch of crystals grown for X-ray crystallography.

Figure S16. ESI-MS in positive mode for crude $\left\{\mathrm{Ni}(\mathrm{dppv})\left[\mathrm{Ni}\left(\mathrm{N}_{2} \mathrm{S2}^{555}\right)\right]\right\}\left(\mathrm{BF}_{4}\right)_{2}$ in $\mathrm{MeCN}$ solutions. Inset: Experimental vs simulated molecular ion peak envelopes. S18 Figure S17. ESI-MS (positive mode) of $\left\{\mathrm{Ni}(\mathrm{dppv})\left[\mathrm{NiN}_{2} \mathrm{~S}_{2}\right]\right\}\left(\mathrm{BF}_{4}\right)_{2}$ in acetone solutions. Inset: Experimental vs simulated molecular ion peak envelopes. Sample was prepared from the batch of crystals grown for X-ray crystallography.

Figure S18. Optimized structures and relative energies (in $\mathrm{kcal} / \mathrm{mol}$ ) for high and low spin isomers of 9 . Atom coloring: $\mathrm{Ni}=$ green, $\mathrm{Fe}=$ orange, $\mathrm{N}=$ blue, $\mathrm{P}=$ purple, $\mathrm{S}=$ yellow, $\mathrm{C}=$ grey. $\mathrm{H}$ atoms omitted for clarity. S20

Figure S19. Thermodynamic speciation of various isomers of $\left\{\left[\mathrm{Ni}\left(\mathrm{N} 2 \mathrm{~S} 2^{555}\right)\right] \mathrm{FeCl}(\mathrm{CO})(\mathrm{dppv})\right\}^{+}$(complex/compound 1 in SFLY nomenclature).

Figure S20. Optimized structures and relative energies (in $\mathrm{kcal} / \mathrm{mol}$, black values) of isomers of 1. Values for Fe-S1 and Fe-S2 distances (in $\AA$ ) are reported in dark blue. Values in parenthesis of both relative energy and distances.

Figure S21. Energy diagram associated with the scan of Fe-S coordinate (from 6- to 5coordinated $\mathrm{Fe}$ ) at various levels of theory. Points are referred to energy-optimized structures with a constrained Fe-S distance, while crosses indicate pure minima (no constraints).....

Figure S22. Overlay of the two cations in the asymmetric unit of $\{\mathrm{Ni}(\mathrm{Cl})($ dppv)[Ni(N2S2 $\left.\left.\left.{ }^{555}\right)\right]\right\} \mathrm{BF}_{4} \cdot \mathrm{CH}_{2} \mathrm{Cl}_{2}$.

Table S1. Crystallographic refinement parameters of: SFLY's 4 (published), rerefinement of SFLY's data but with $\mathrm{Ni}$ in place of Fe, SFLY's $\mathbf{5}$ (published), rerefinement of SFLY's data but with $\mathrm{Ni}$ in place of $\mathrm{Fe}$.

Table S2. Crystallographic refinement parameters of: SFLY's 7 (published ${ }^{1}$ ) and rerefinement of SFLY's data but with $\mathrm{Ni}$ in place of $\mathrm{Fe}$.

Table S3. Crystallographic refinement parameters of: SFLY's 9 (published ${ }^{1}$ ) ; rerefinement of SFLY's data but with $\mathrm{Ni}$ in place of $\mathrm{Fe}$, and the $\mathrm{Ni}-\mathrm{Ni}$ compound prepared in this work 
S3

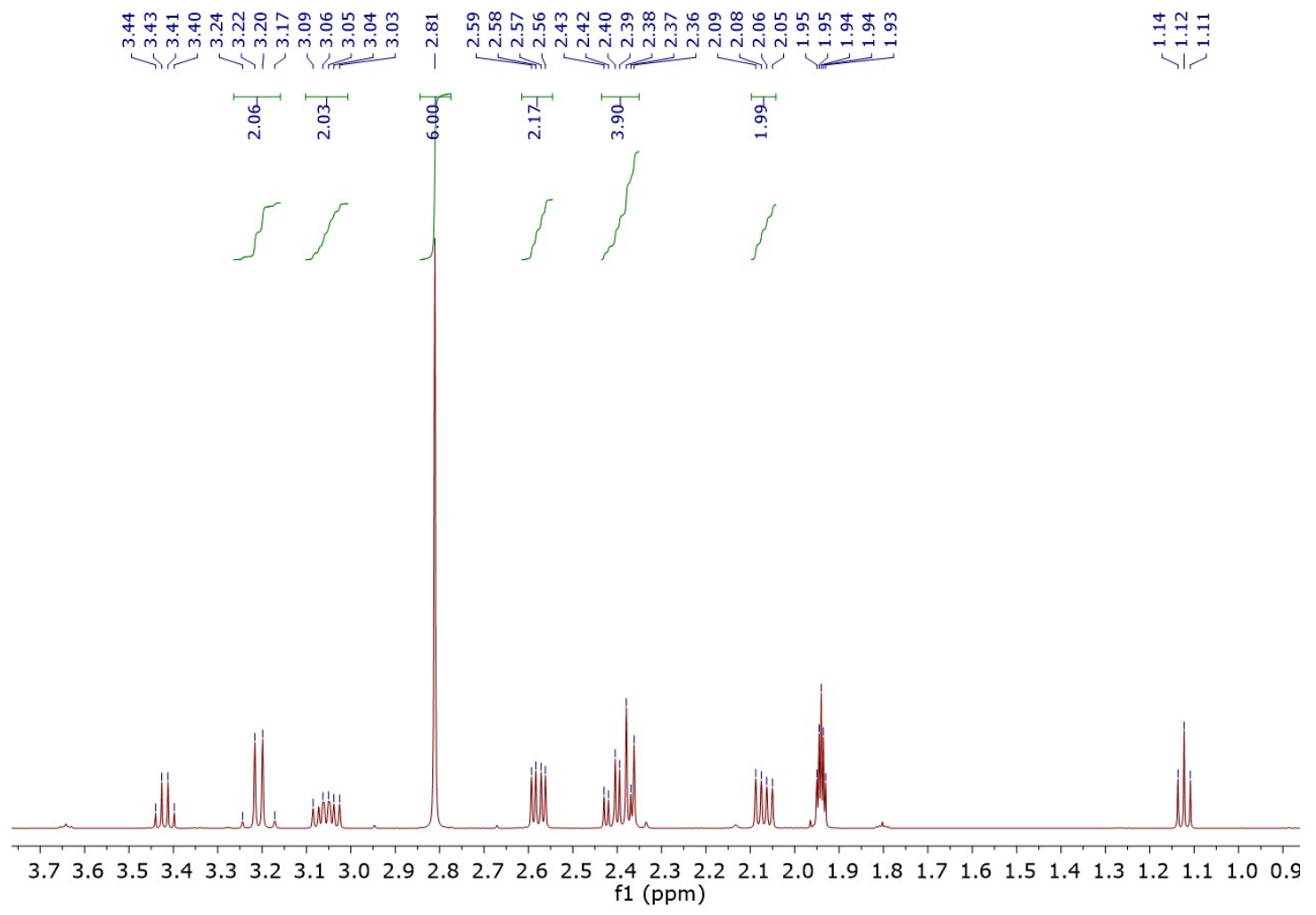

Figure S1. ${ }^{1} \mathrm{H}-\mathrm{NMR}$ spectrum of $\mathrm{Ni}\left(\mathrm{N} 2 \mathrm{~S}^{555}\right)$ in $\mathrm{CD}_{3} \mathrm{CN}$ solution. 


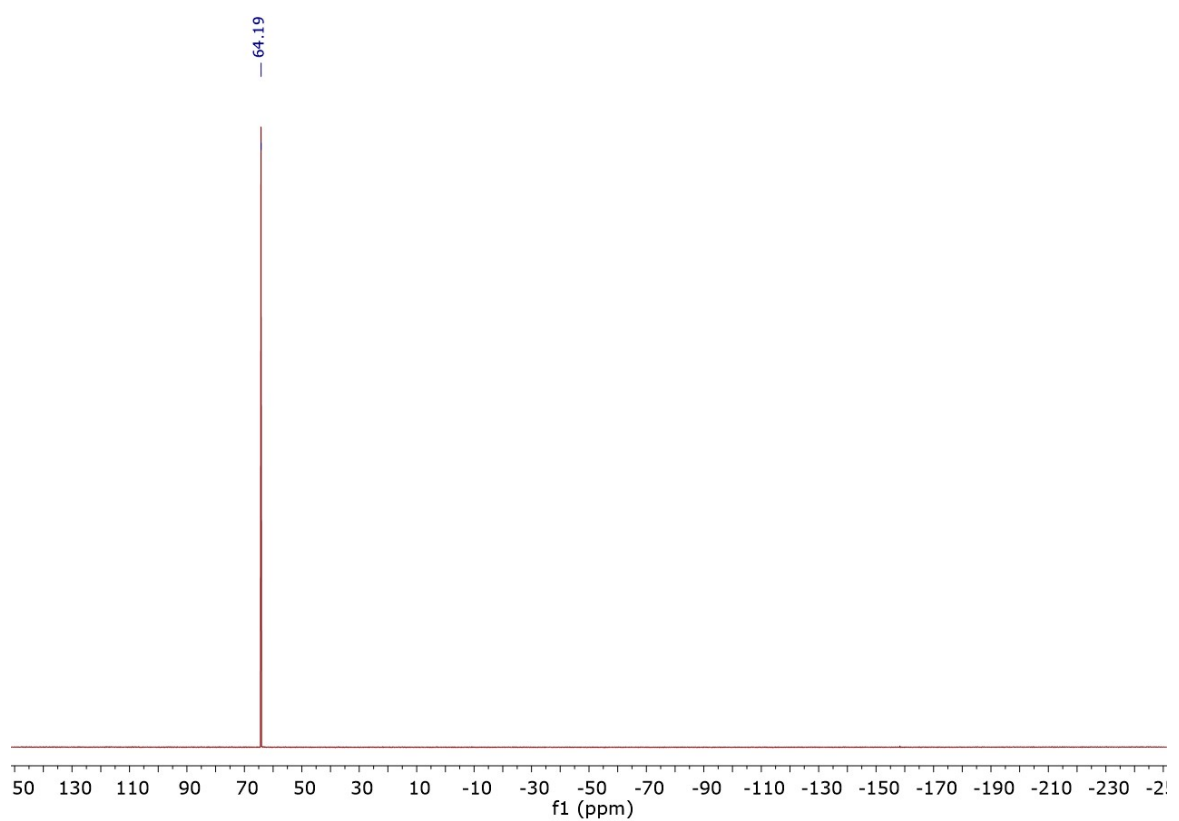

Figure S2. ${ }^{31} \mathrm{P}-\mathrm{NMR}$ spectrum of $\mathrm{NiCl}_{2}(\mathrm{dppv})$ in $\mathrm{CH}_{2} \mathrm{Cl}_{2}$ solution. 

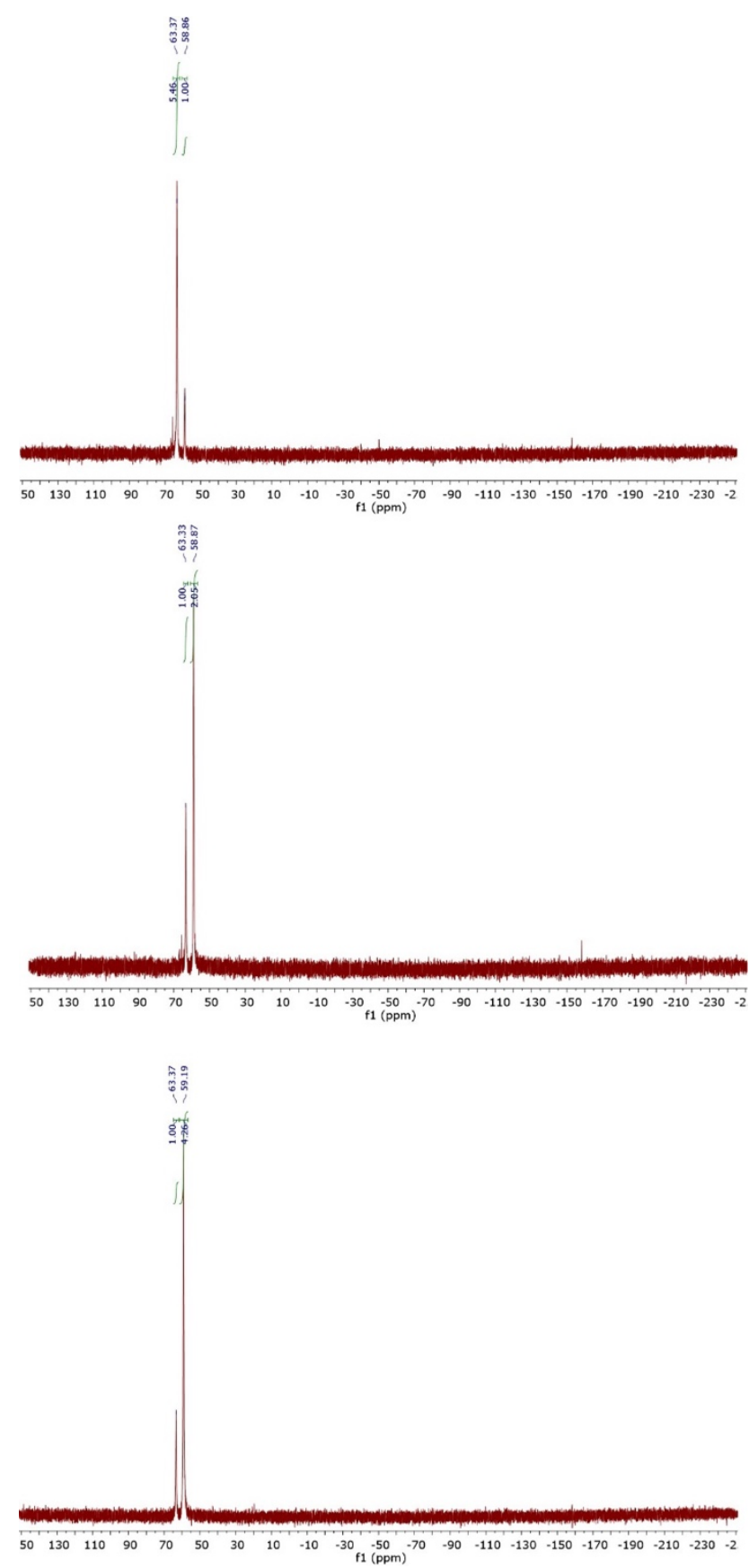

Figure S3. ${ }^{31} \mathrm{P}-\mathrm{NMR}$ spectra for the reaction of $\mathrm{Ni}\left(\mathrm{N} 2 \mathrm{~S}^{555}\right)$ and $\mathrm{NiCl}_{2}(\mathrm{dppv})$ in $\mathrm{MeCN}$ solution. Top: $2 \mathrm{~h}$ ( $15 \%$ conversion). Middle: $12 \mathrm{~h}$ ( $67 \%$ conversion). Bottom: $36 \mathrm{~h}$ ( $80 \%$ conversion). 


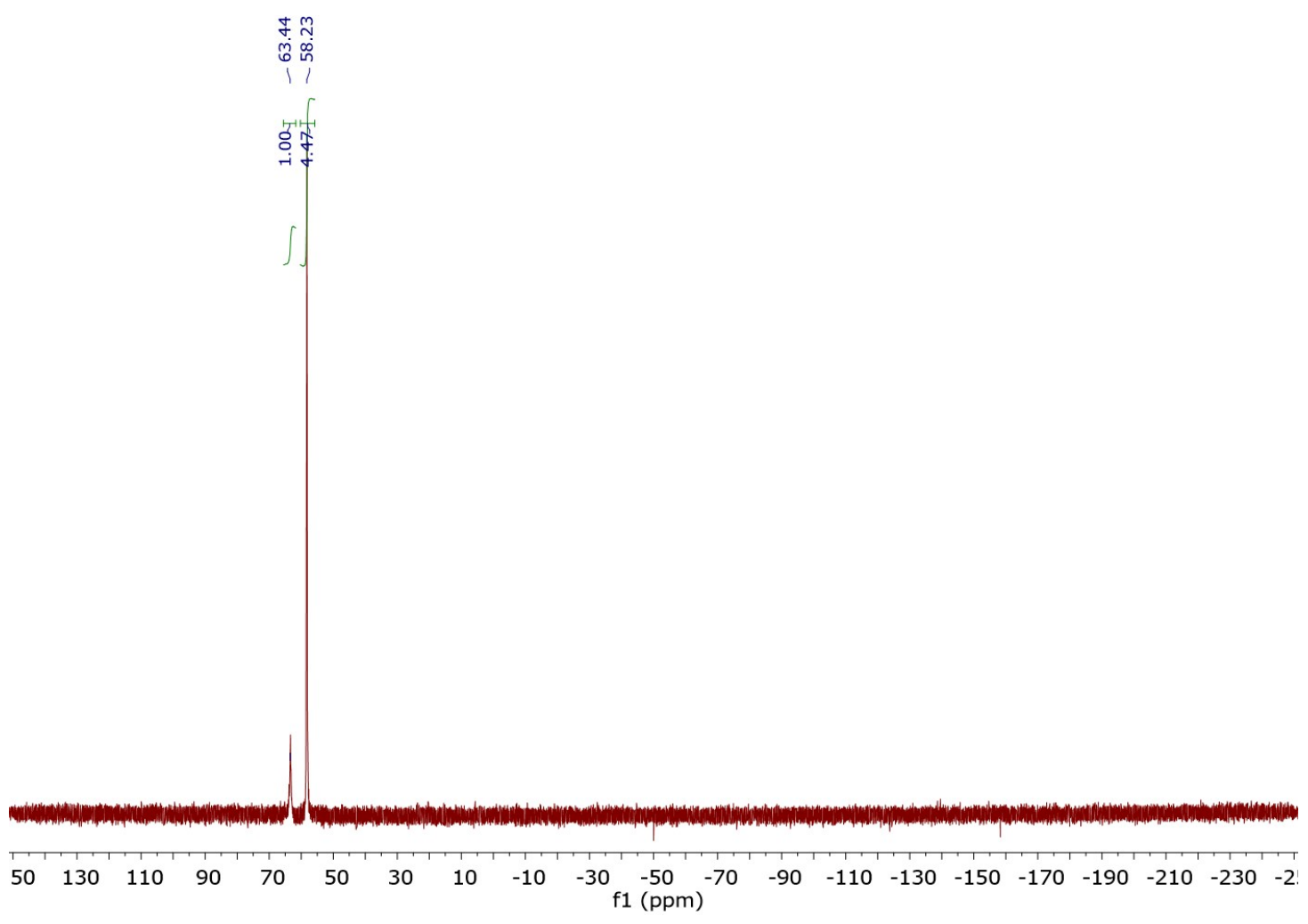

Figure S4. ${ }^{31} \mathrm{P}-\mathrm{NMR}$ spectrum of product(s) of the reaction of $\mathrm{Ni}\left(\mathrm{N} 2 \mathrm{~S} 2{ }^{555}\right)$ and $\mathrm{NiCl}_{2}$ (dppv) in acetone solution after $10 \mathrm{~h}$ ( 80\% conversion). 


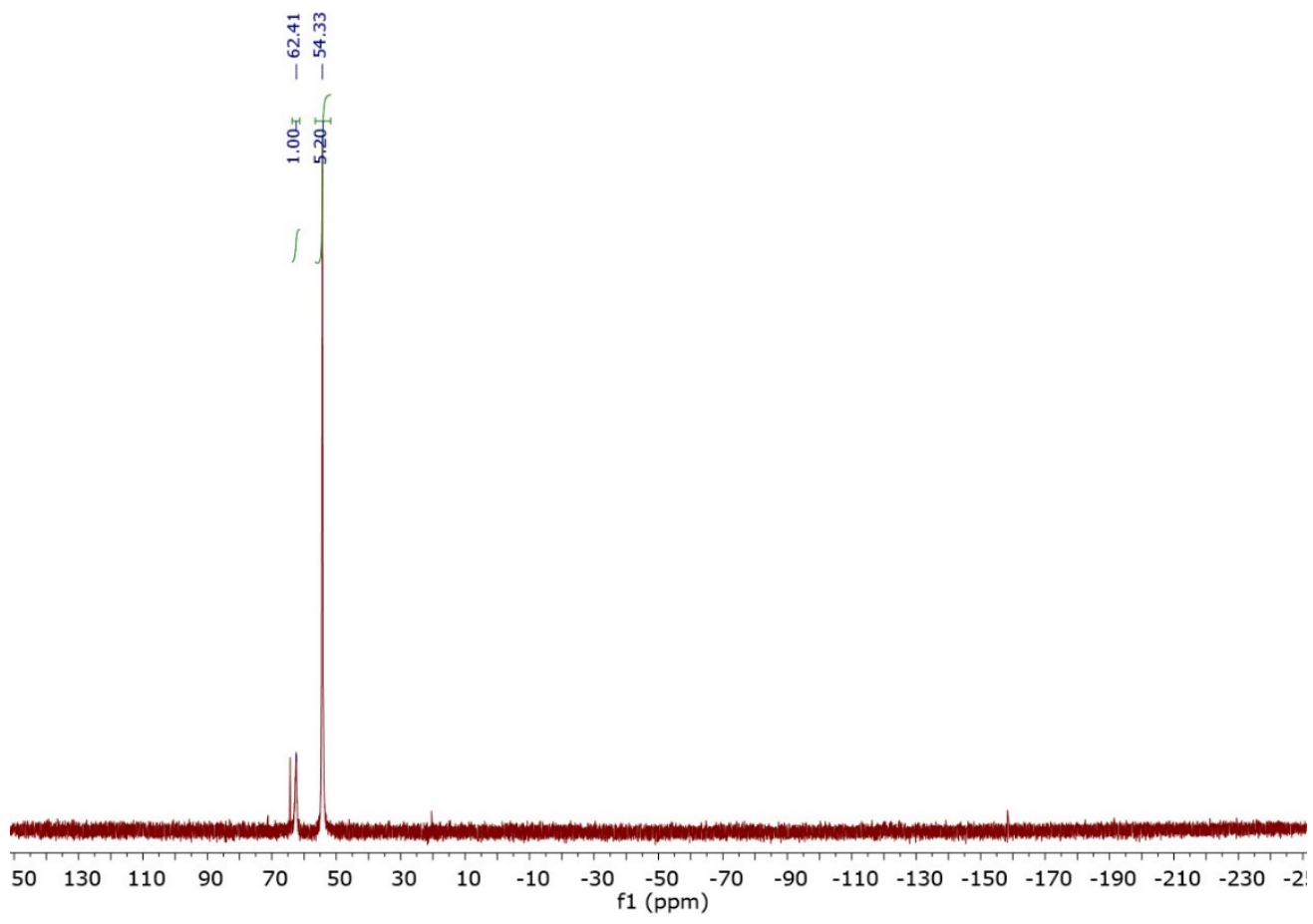

Figure S5. ${ }^{31} \mathrm{P}-\mathrm{NMR}$ spectrum of crude $\left\{\mathrm{Ni}(\mathrm{Cl})(\mathrm{dppv})\left[\mathrm{Ni}\left(\mathrm{N} 2 \mathrm{~S}^{555}\right)\right]\right\} \mathrm{BF}_{4}$ in $\mathrm{CDCl}_{3}$ solution. 


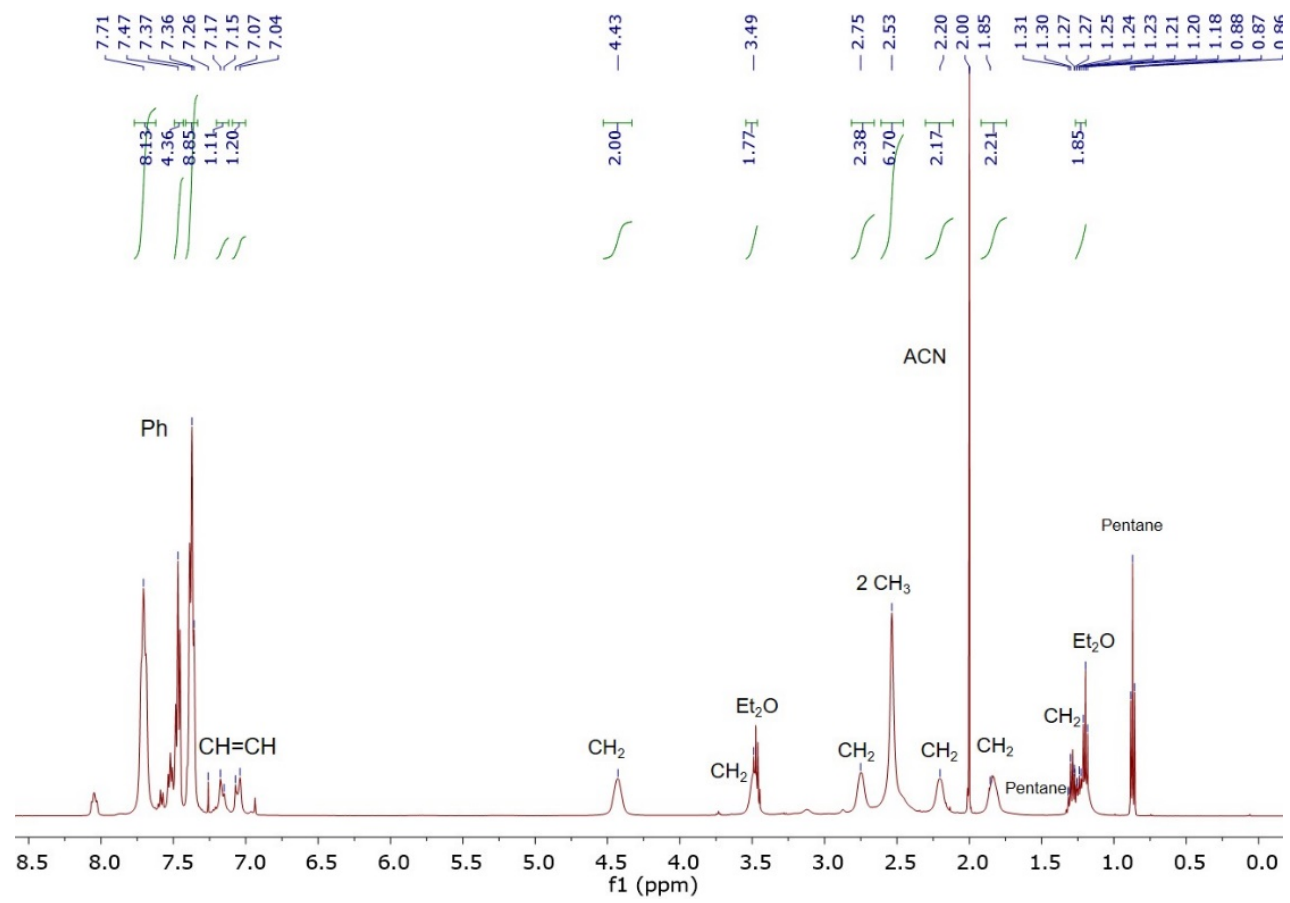

Figure S6. ${ }^{1} \mathrm{H}-\mathrm{NMR}$ spectrum of crude $\left\{\mathrm{Ni}(\mathrm{Cl})(\mathrm{dppv})\left[\mathrm{Ni}\left(\mathrm{N} 2 \mathrm{~S}^{555}\right)\right]\right\} \mathrm{BF} \mathrm{F}_{4}$ in $\mathrm{CDCl}_{3}$ solution. 


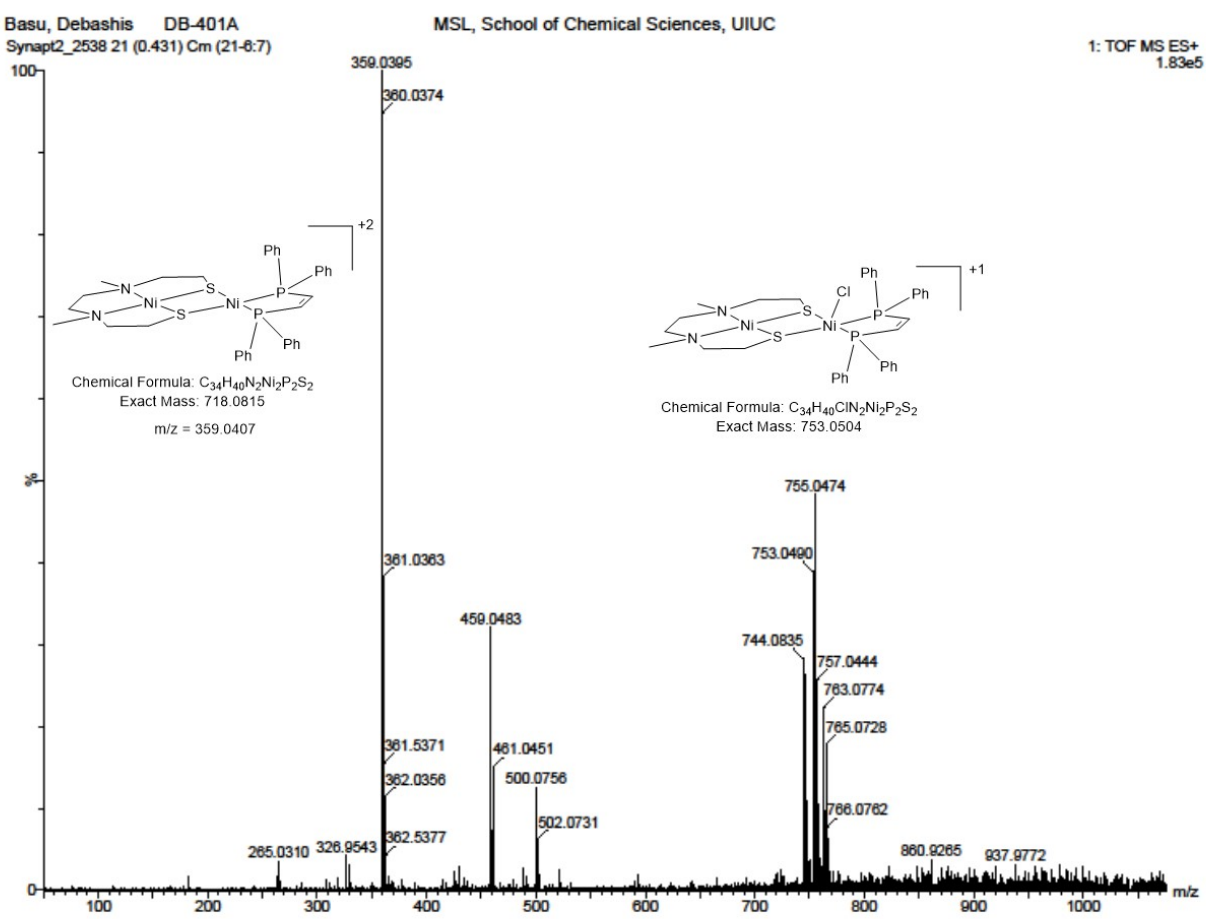

Figure S7. ESI-MS (positive mode) of $\left\{\mathrm{Ni}(\mathrm{Cl})(\mathrm{dppv})\left[\mathrm{Ni}\left(\mathrm{N}_{2} \mathrm{~S}_{2}{ }^{555}\right)\right]\right\} \mathrm{BF}_{4}$ in $\mathrm{MeCN}$ solution. 
Single Mass Analysis

Tolerance $=5.0$ PPM / DBE: $\min =-1.5, \max =200.0$

Element prediction: Off

Number of isotope peaks used for $\mathrm{i}-\mathrm{FIT}=9$

Monoisotopic Mass, Even Electron lons

173 formula(e) evaluated with 2 results within limits (up to 50 best isotopic matches for each mass)

Elements Used:

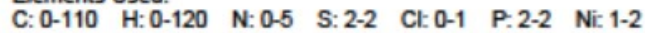

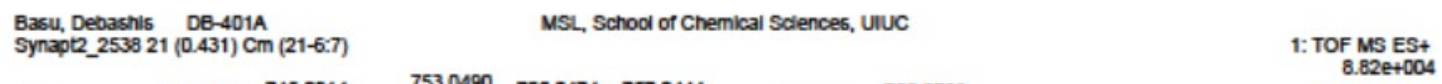

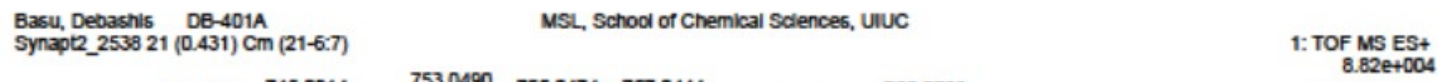

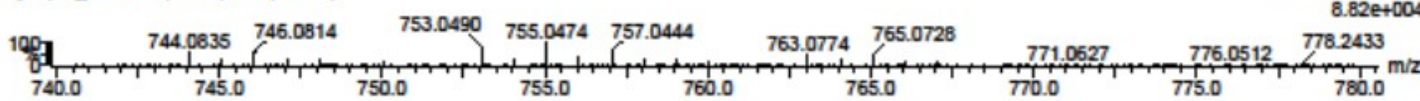

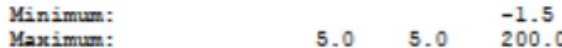

Mass Calc. Mass mDa PPM DBE i-FTT Norm Conf(s) Formula

$\begin{array}{llllllllll}753.0490 & 753.0504 & -1.4 & -1.9 & 17.5 & 637.1 & 0.000 & 100.00 & \text { C34 H40 N2 S2 C1 P2 Ni2 } & \text { N2 }\end{array}$

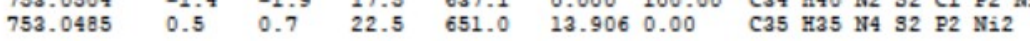

Figure S8. Elemental composition report for ESI-MS in positive mode for $\left\{\mathrm{Ni}(\mathrm{Cl})(\mathrm{dppv})\left[\mathrm{Ni}\left(\mathrm{N} 2 \mathrm{~S}^{555}\right)\right]\right\} \mathrm{BF}_{4}$ in $\mathrm{MeCN}$ solution. 


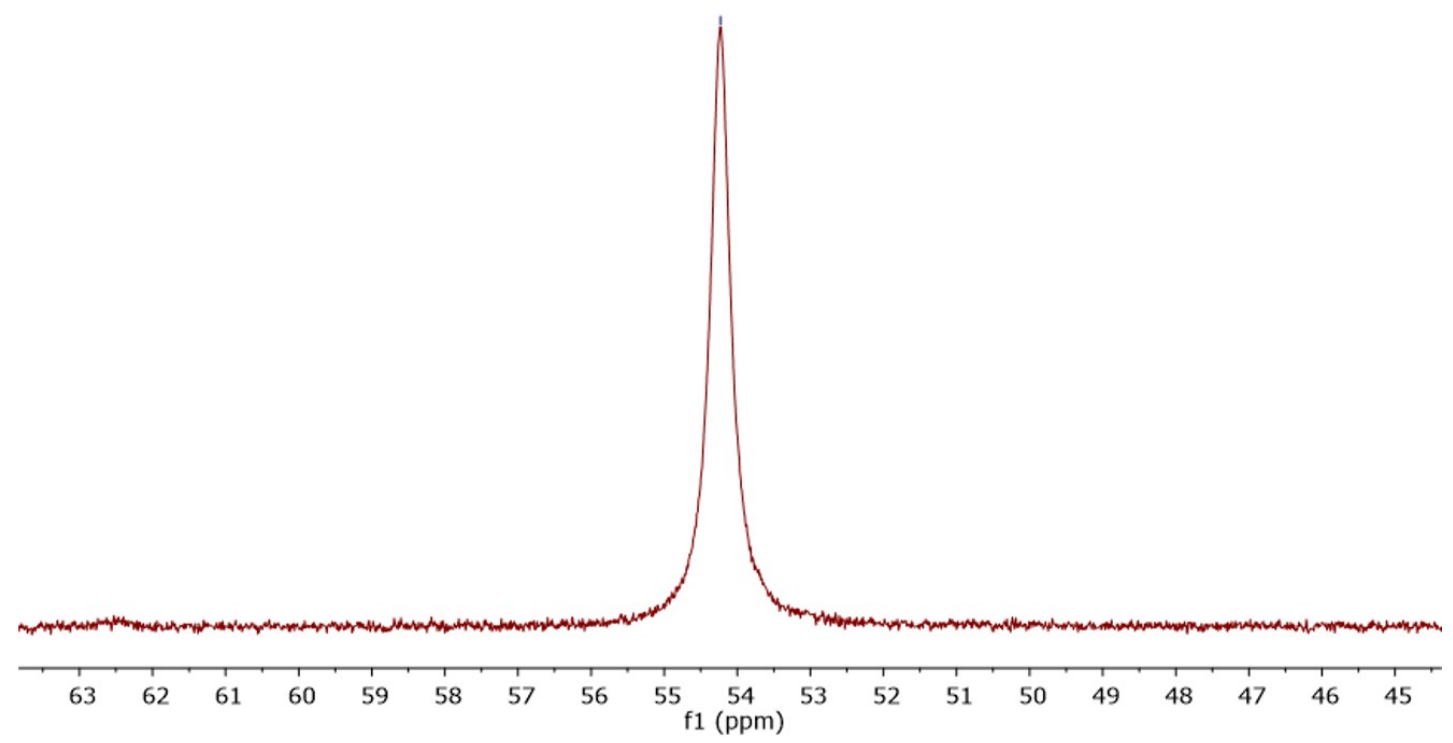

Figure S9. ${ }^{31} \mathrm{P}-\mathrm{NMR}$ spectrum (expanded) of $\left\{\mathrm{Ni}(\mathrm{Cl})(\mathrm{dppv})\left[\mathrm{Ni}\left(\mathrm{N}^{2} \mathrm{~S}^{555}\right)\right]\right\} \mathrm{BF}_{4}$ in $\mathrm{CDCl}_{3}$ solution. The sample was prepared from the batch of crystals analyzed by X-ray crystallography. 

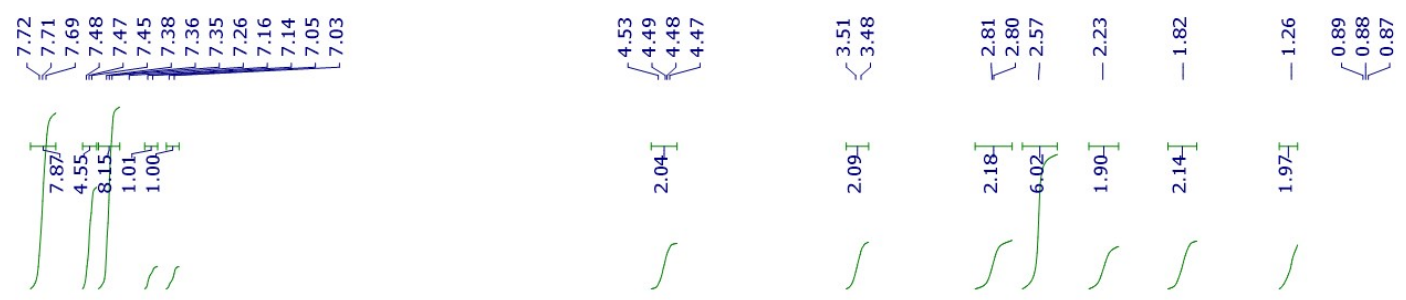

ग
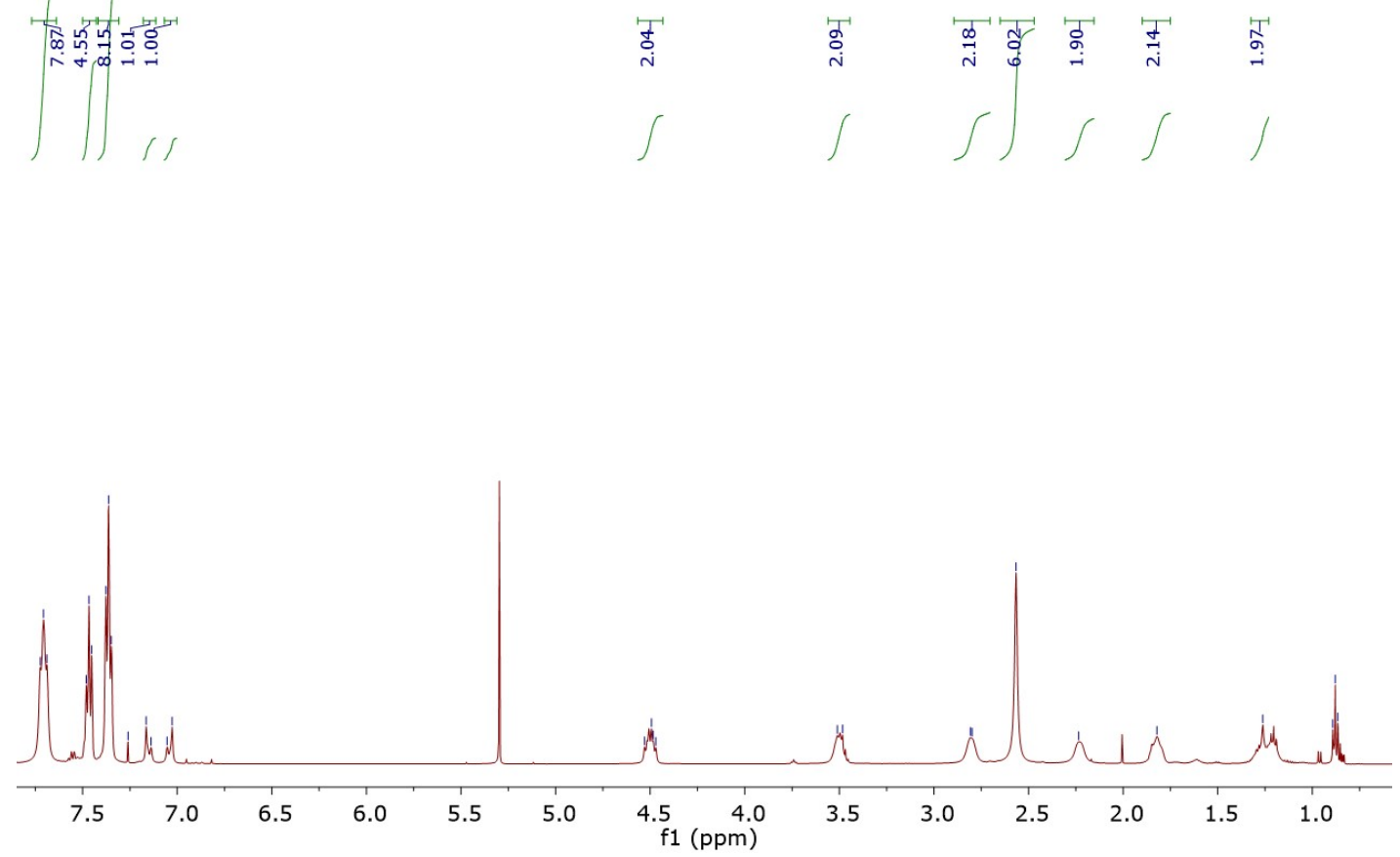

Figure S10. ${ }^{1} \mathrm{H}-\mathrm{NMR}$ spectrum of $\left\{\mathrm{Ni}(\mathrm{Cl})(\mathrm{dppv})\left[\mathrm{Ni}\left(\mathrm{N}_{2} \mathrm{~S}^{555}\right)\right]\right\} \mathrm{BF}_{4}$ in $\mathrm{CDCl}_{3}$ solution. The sample was prepared from the batch of crystals analyzed by X-ray crystallography. 
S13
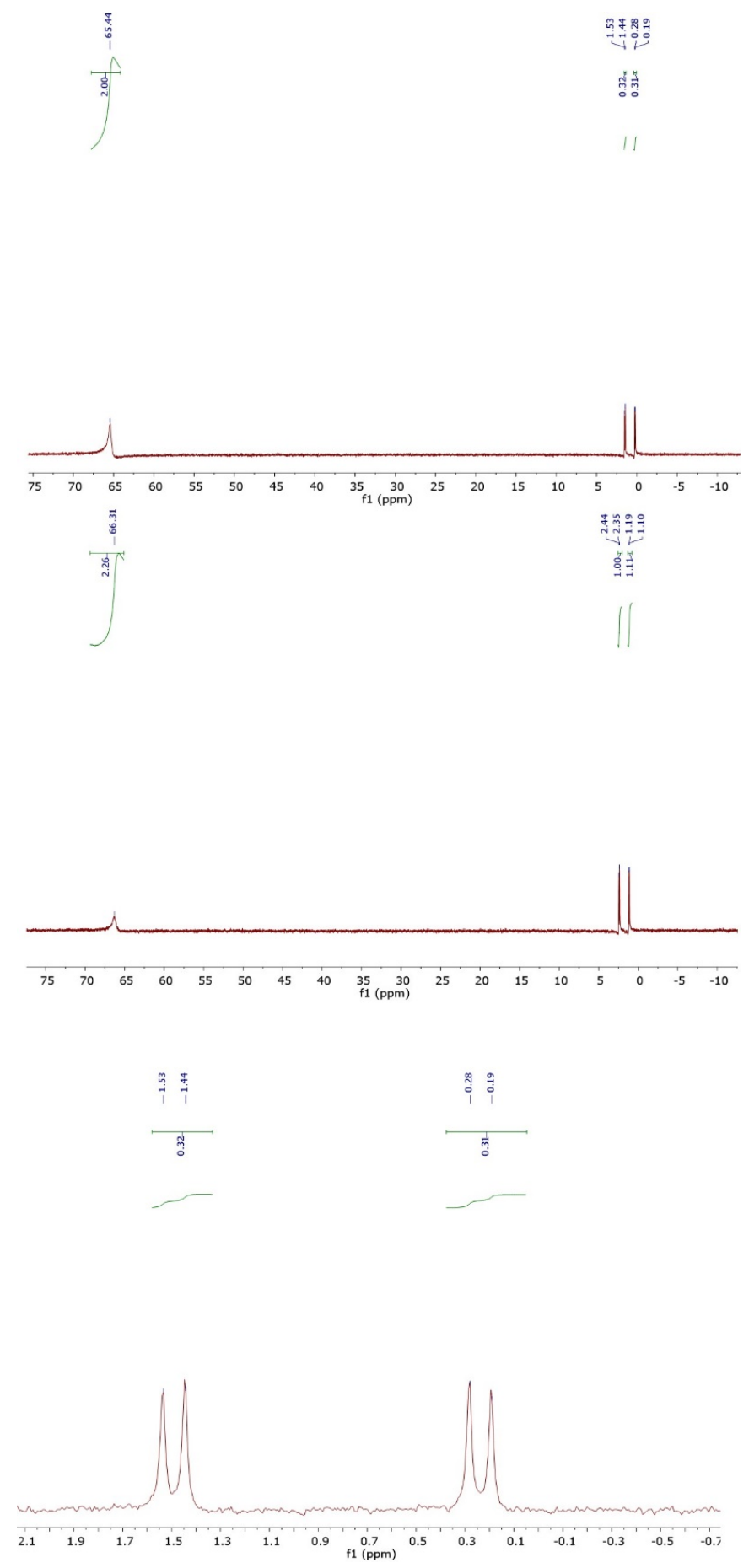

Figure S11. ${ }^{31} \mathrm{P}-\mathrm{NMR}$ spectra of the reaction of $\left\{\mathrm{Ni}(\mathrm{Cl})(\mathrm{dppv})\left[\mathrm{Ni}\left(\mathrm{N} 2 \mathrm{~S}^{555}\right)\right]\right\} \mathrm{BF}_{4}$ and $\mathrm{AgBF}_{4}$ in MeCN solution. Top: 30 min. ( $\sim 87 \%$ desired complex). Middle: $3 \mathrm{~h}$ (68 \% desired complex). Bottom: expanded high field region. 

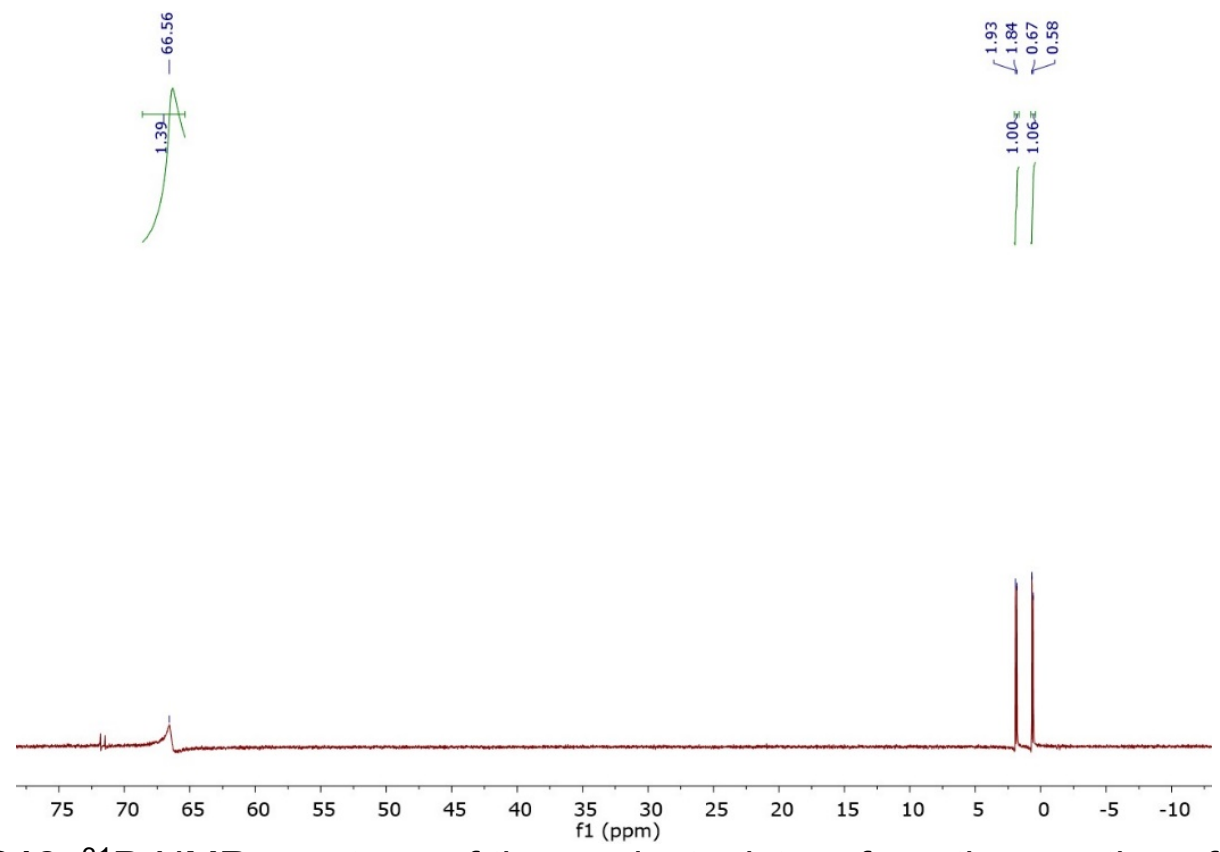

Figure S12. ${ }^{31} \mathrm{P}-\mathrm{NMR}$ spectrum of the product mixture from the reaction of $\mathrm{NiCl}_{2}(\mathrm{dppv})$ and $\mathrm{Ni}\left(\mathrm{N} 2 \mathrm{~S}^{555}\right)$ in $\mathrm{CD}_{3} \mathrm{COCD}_{3}$ solution. 
S15

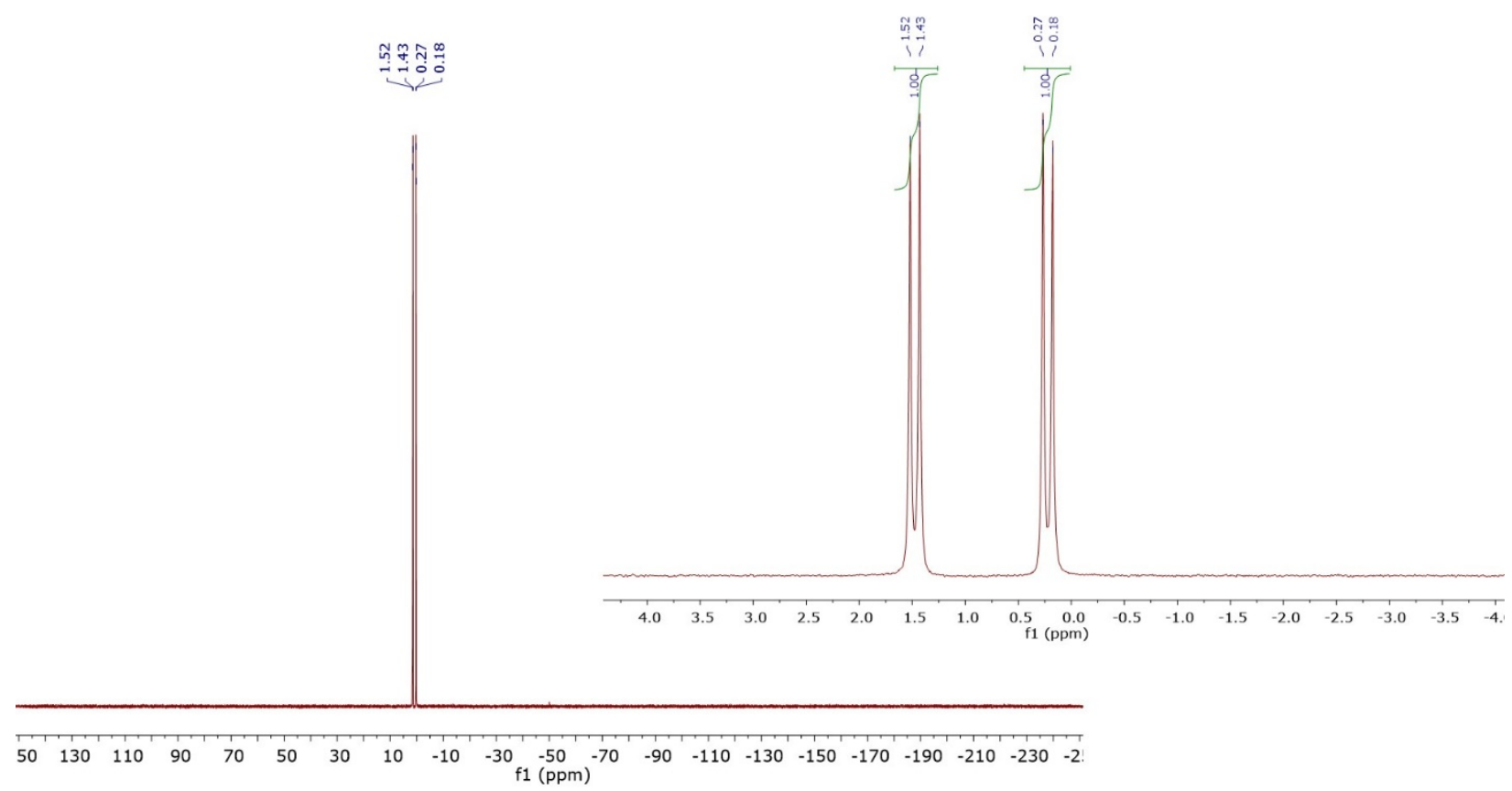

Figure S13. ${ }^{31} \mathrm{P}-\mathrm{NMR}$ spectrum of $\left[\mathrm{Ag}(\mathrm{dppv})_{2}\right] \mathrm{BF}_{4}$ in $\mathrm{MeCN}$ solution. 
S16

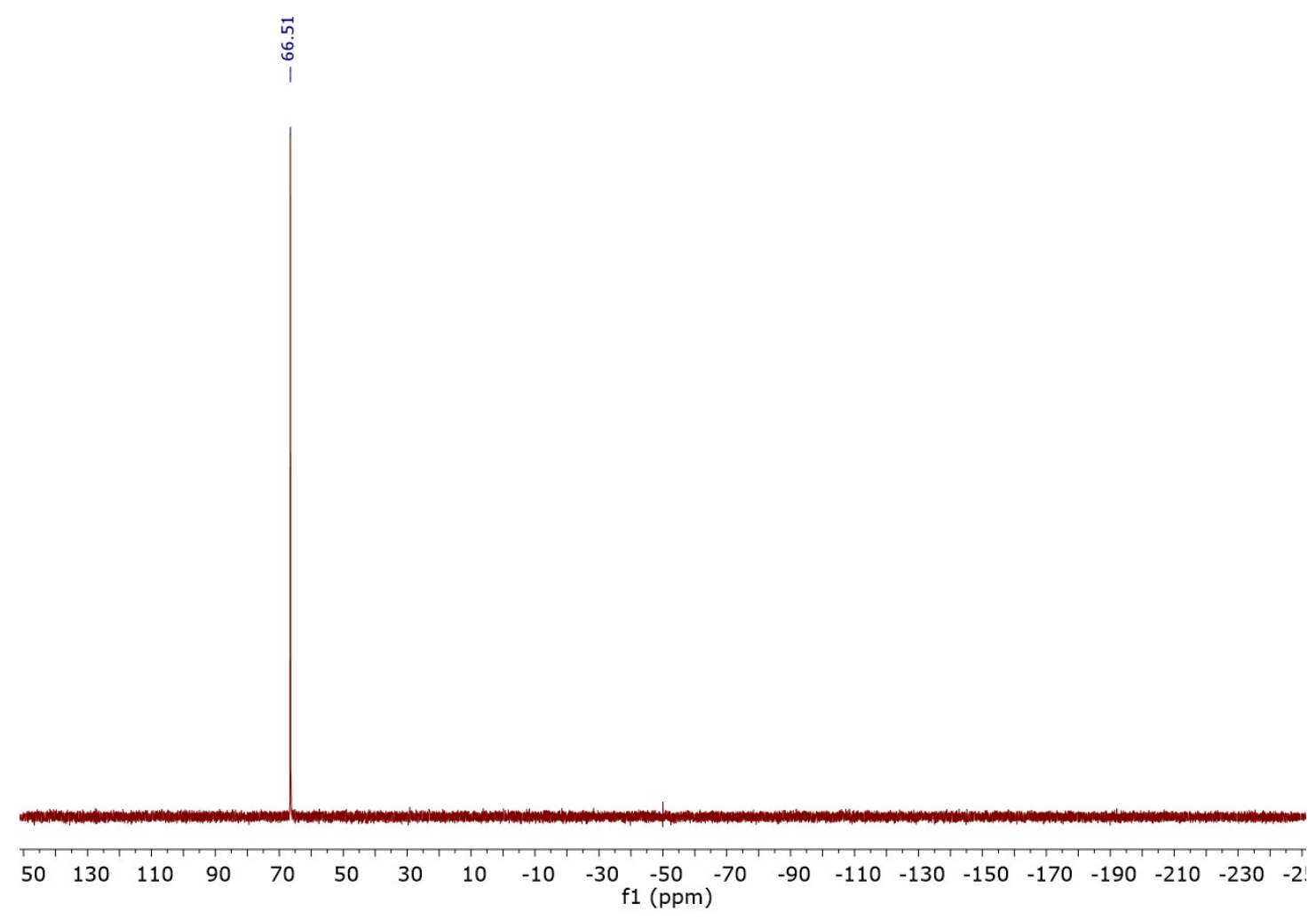

Figure S14. ${ }^{31} \mathrm{P}-\mathrm{NMR}$ spectrum of $\left\{\mathrm{Ni}(\mathrm{dppv})\left[\mathrm{Ni}\left(\mathrm{N} 2 \mathrm{~S}^{555}\right)\right]\right\}\left(\mathrm{BF}_{4}\right)_{2}$ in $\mathrm{CD}_{3} \mathrm{COCD}_{3}$ solution. Sample was prepared from the batch of crystals grown for X-ray crystallography. 

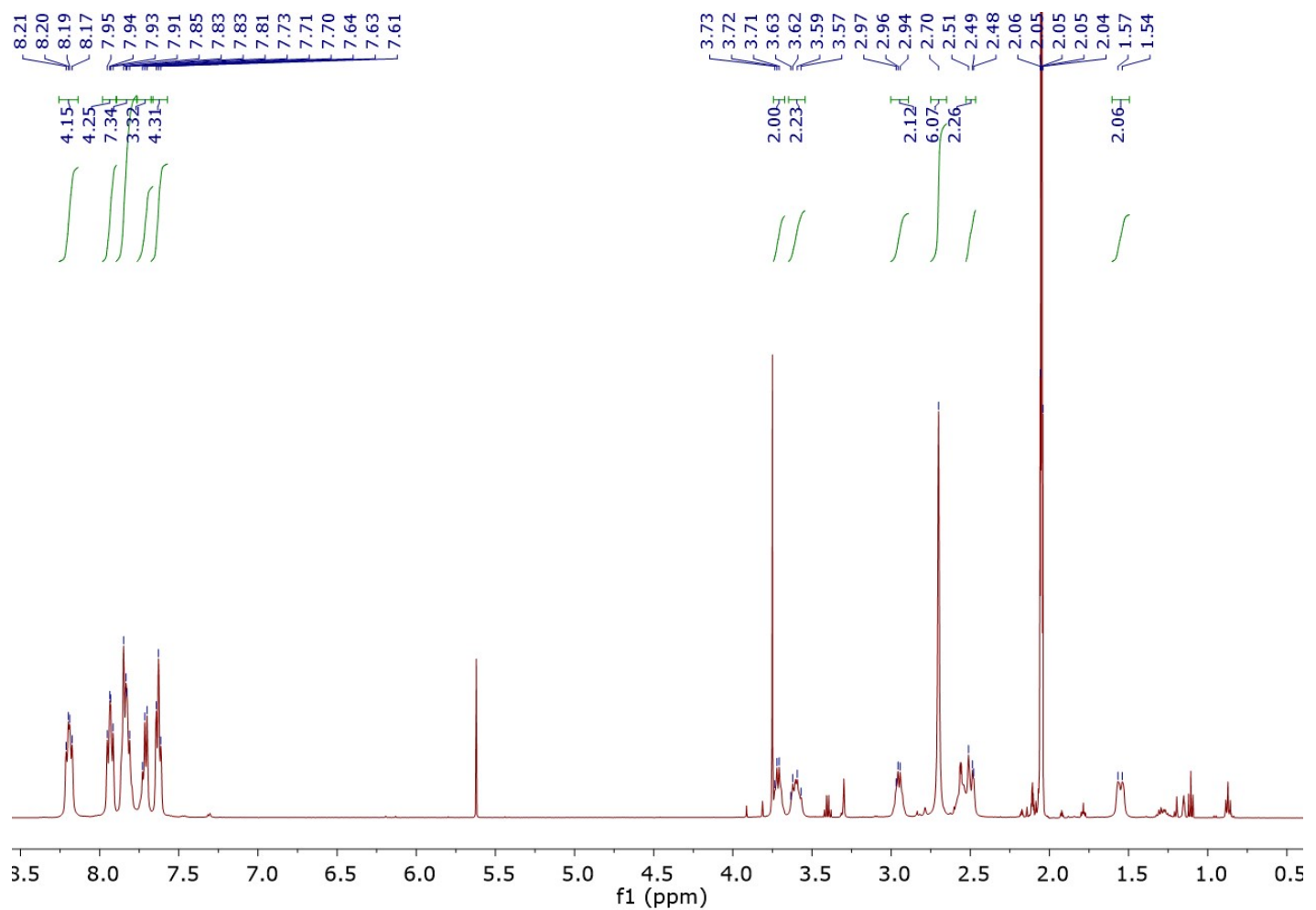

Figure S15. ${ }^{1} \mathrm{H}-\mathrm{NMR}$ spectrum of the $\left\{\mathrm{Ni}(\mathrm{dppv})\left[\mathrm{Ni}\left(\mathrm{N} 2 \mathrm{~S}^{255}\right)\right]\right\}\left(\mathrm{BF}_{4}\right)_{2}$ in $\mathrm{CD}_{3} \mathrm{COCD}_{3}$ solution. Sample was prepared from the batch of crystals grown for X-ray crystallography. 


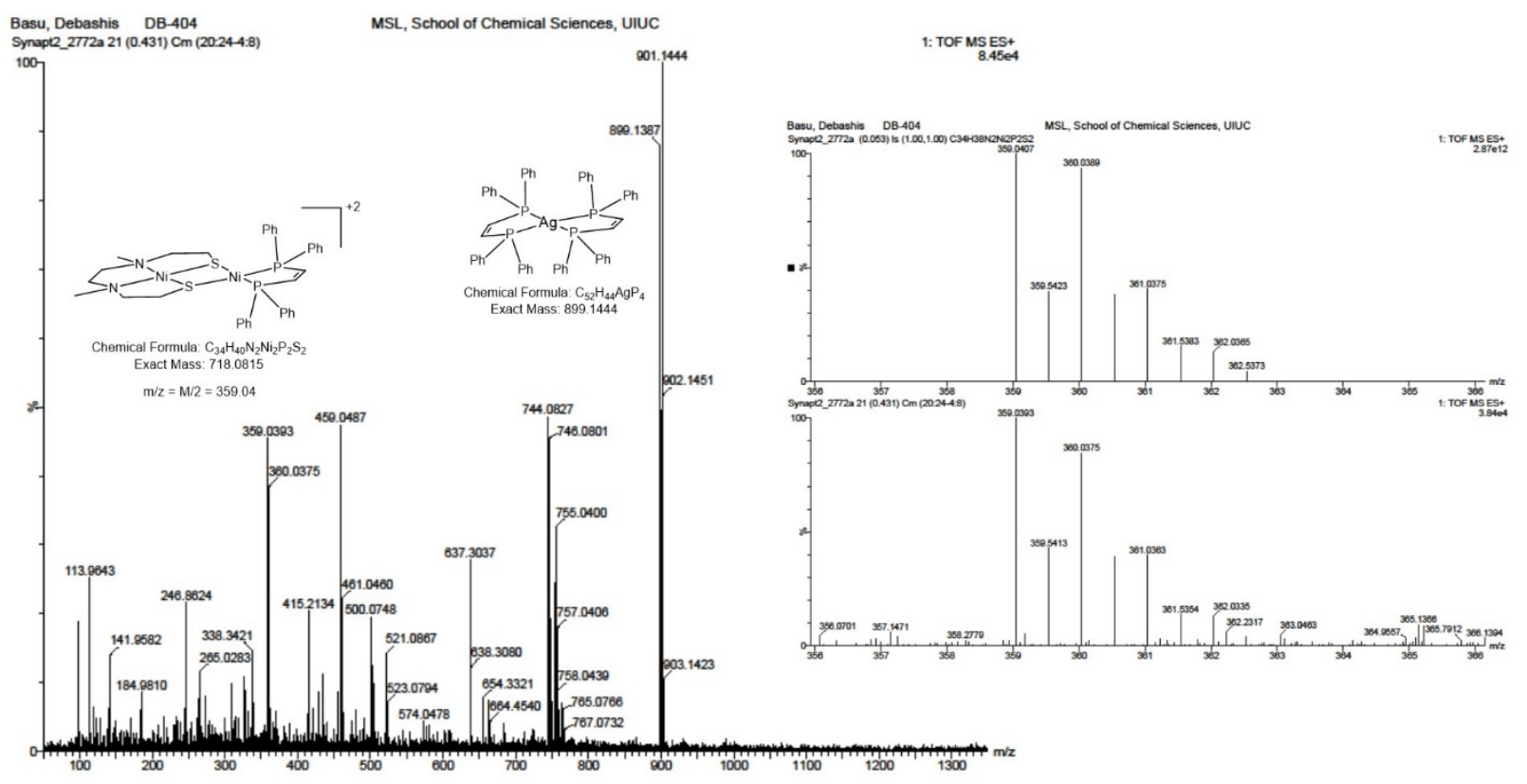

Figure S16. ESI-MS in positive mode for crude $\left\{\mathrm{Ni}(\mathrm{dppv})\left[\mathrm{Ni}\left(\mathrm{N}_{2} \mathrm{~S}^{555}\right)\right]\right\}\left(\mathrm{BF}_{4}\right)_{2}$ in $\mathrm{MeCN}$ solutions. Inset: Experimental vs simulated molecular ion peak envelopes. 


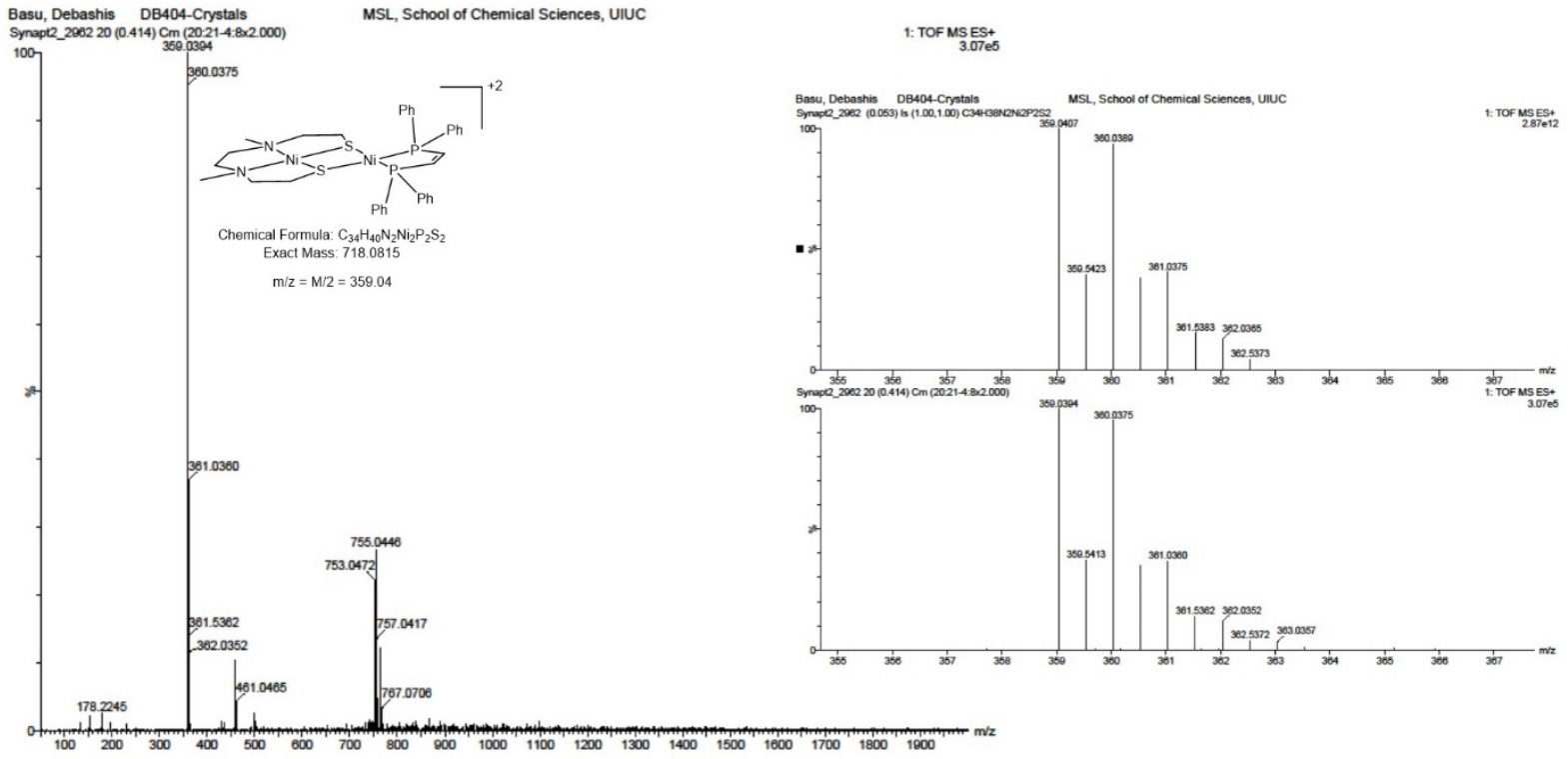

Figure S17. ESI-MS (positive mode) of $\left\{\mathrm{Ni}(\mathrm{dppv})\left[\mathrm{NiN}_{2} \mathrm{~S}_{2}\right]\right\}\left(\mathrm{BF}_{4}\right)_{2}$ in acetone solutions. Inset: Experimental vs simulated molecular ion peak envelopes. Sample was prepared from the batch of crystals grown for X-ray crystallography. 


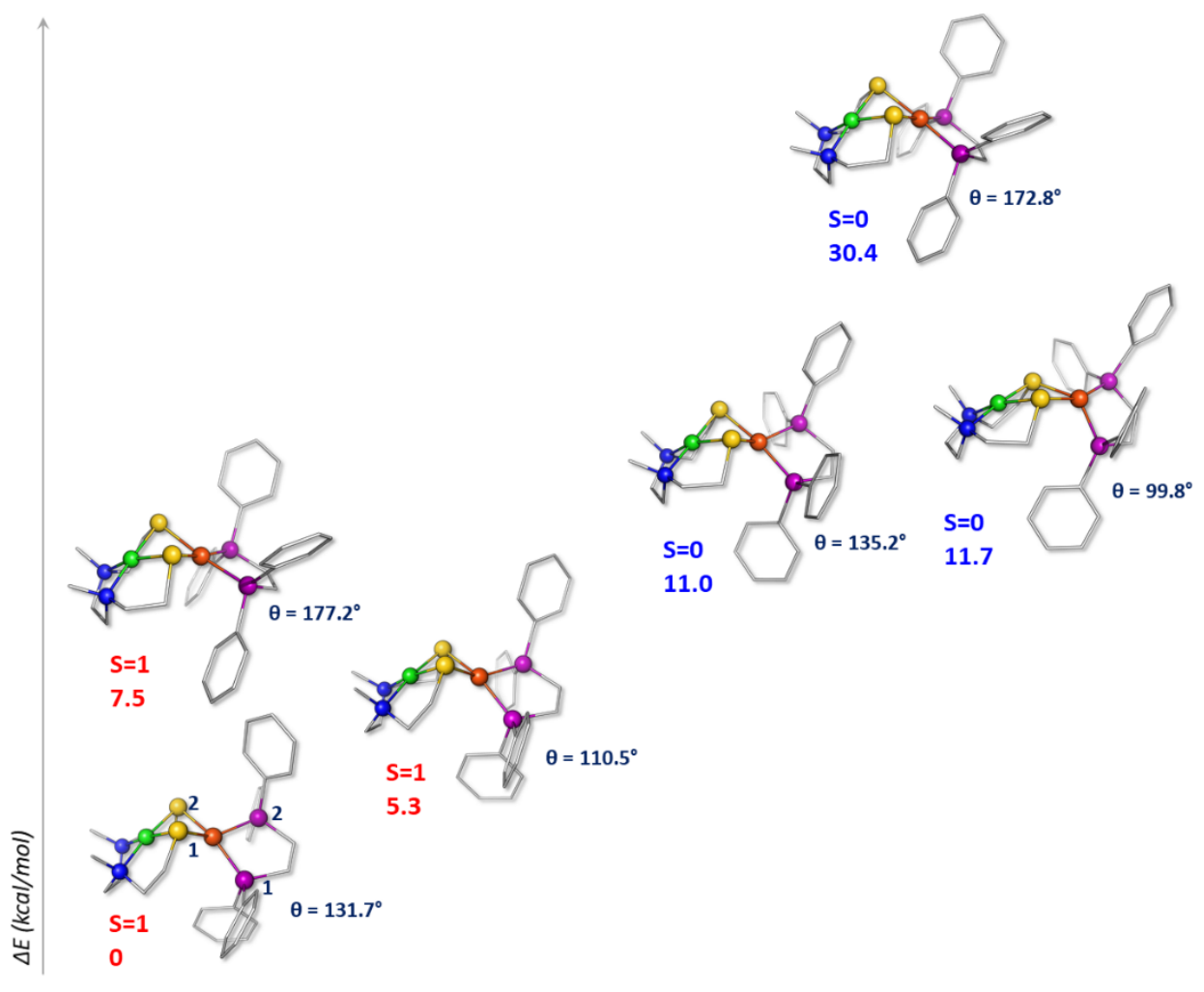

Figure S18. Optimized structures and relative energies (in $\mathrm{kcal} / \mathrm{mol}$ ) for high and low spin isomers of 9 . Atom coloring: $\mathrm{Ni}=$ green, $\mathrm{Fe}=$ orange, $\mathrm{N}=$ blue, $\mathrm{P}=$ purple, $\mathrm{S}=$ yellow, $\mathrm{C}=$ grey. $\mathrm{H}$ atoms omitted for clarity 

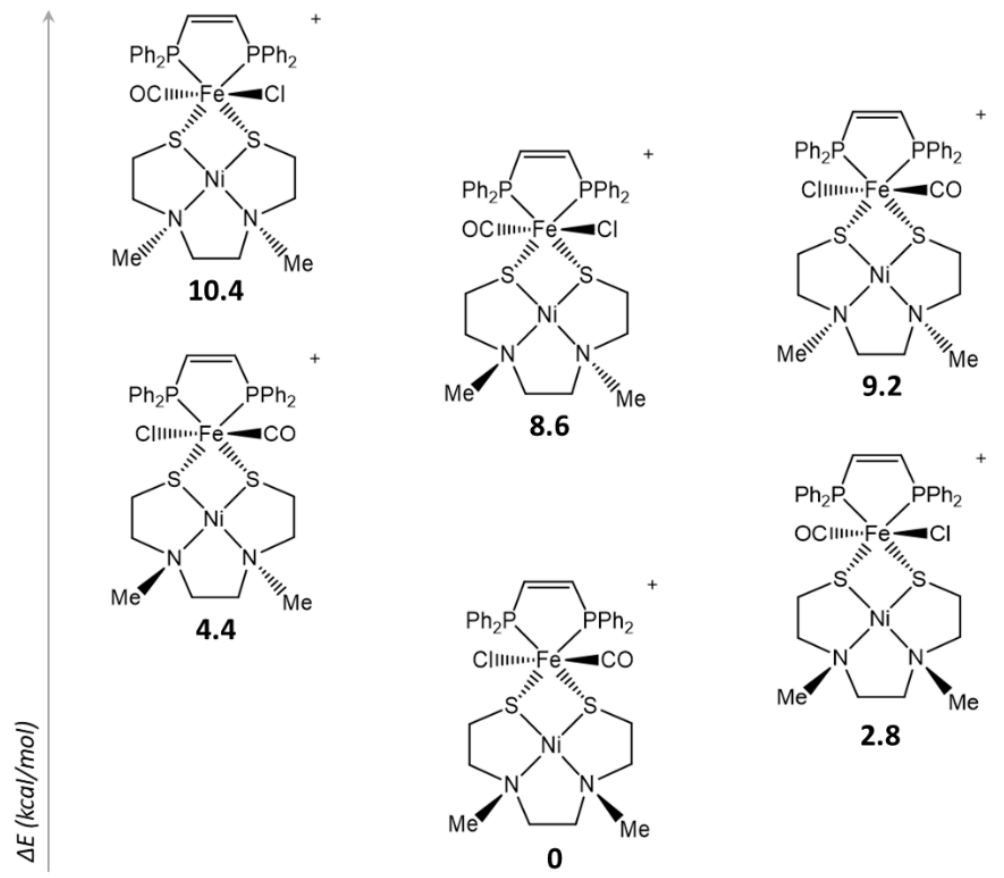

Figure S19. Thermodynamic speciation of various isomers of $\left\{\left[\mathrm{Ni}\left(\mathrm{N} 2 \mathrm{~S} 2^{555}\right)\right] \mathrm{FeCl}(\mathrm{CO})(\mathrm{dppv})\right\}^{+}$(complex/compound 1 in SFLY nomenclature). 


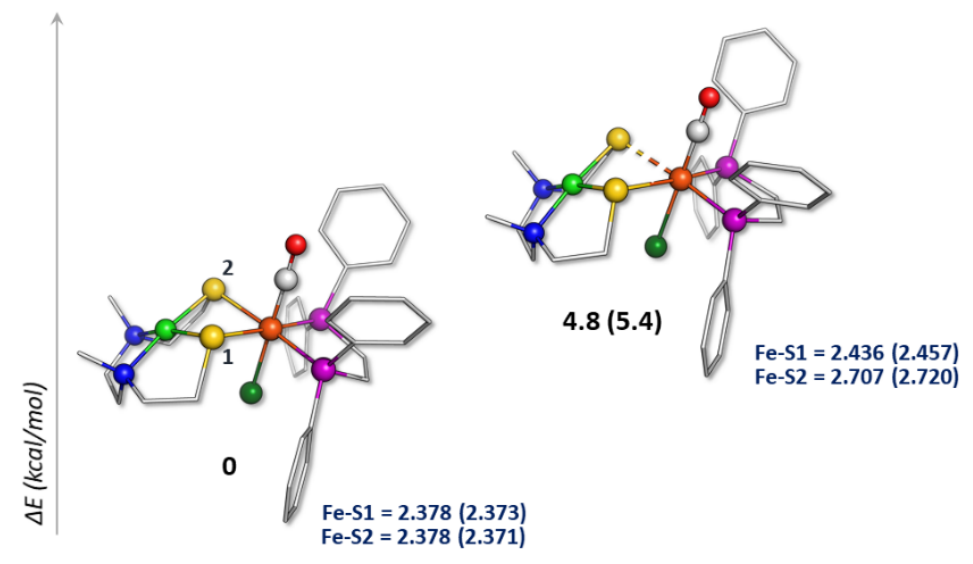

Figure S20. Optimized structures and relative energies (in $\mathrm{kcal} / \mathrm{mol}$, black values) of isomers of 1 . Values for Fe-S1 and Fe-S2 distances (in $\AA$ ) are reported in dark blue. Values in parenthesis of both relative energy and distances. 


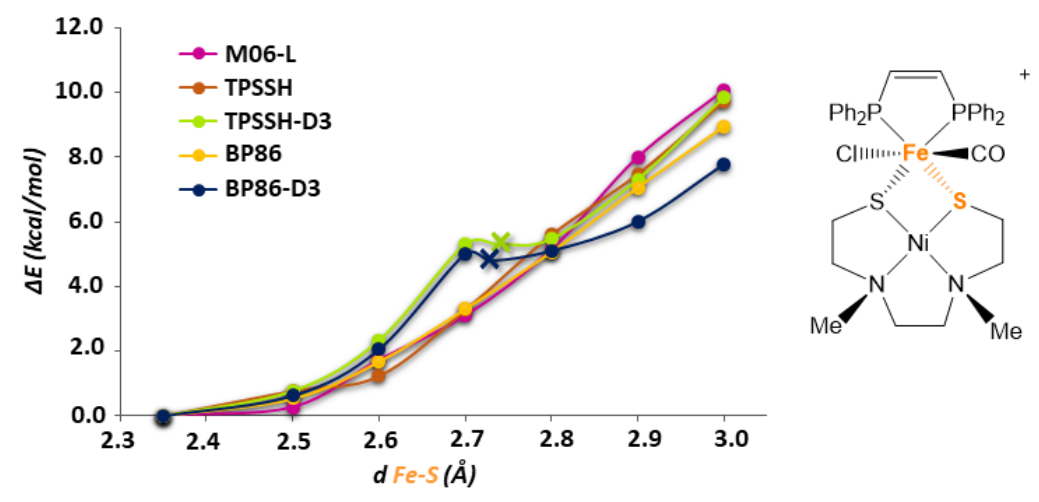

Figure S21. Energy diagram associated with the scan of Fe-S coordinate (from 6- to 5coordinated $\mathrm{Fe}$ ) at various levels of theory. Points are referred to energy-optimized structures with a constrained Fe-S distance, while crosses indicate pure minima (no constraints). 


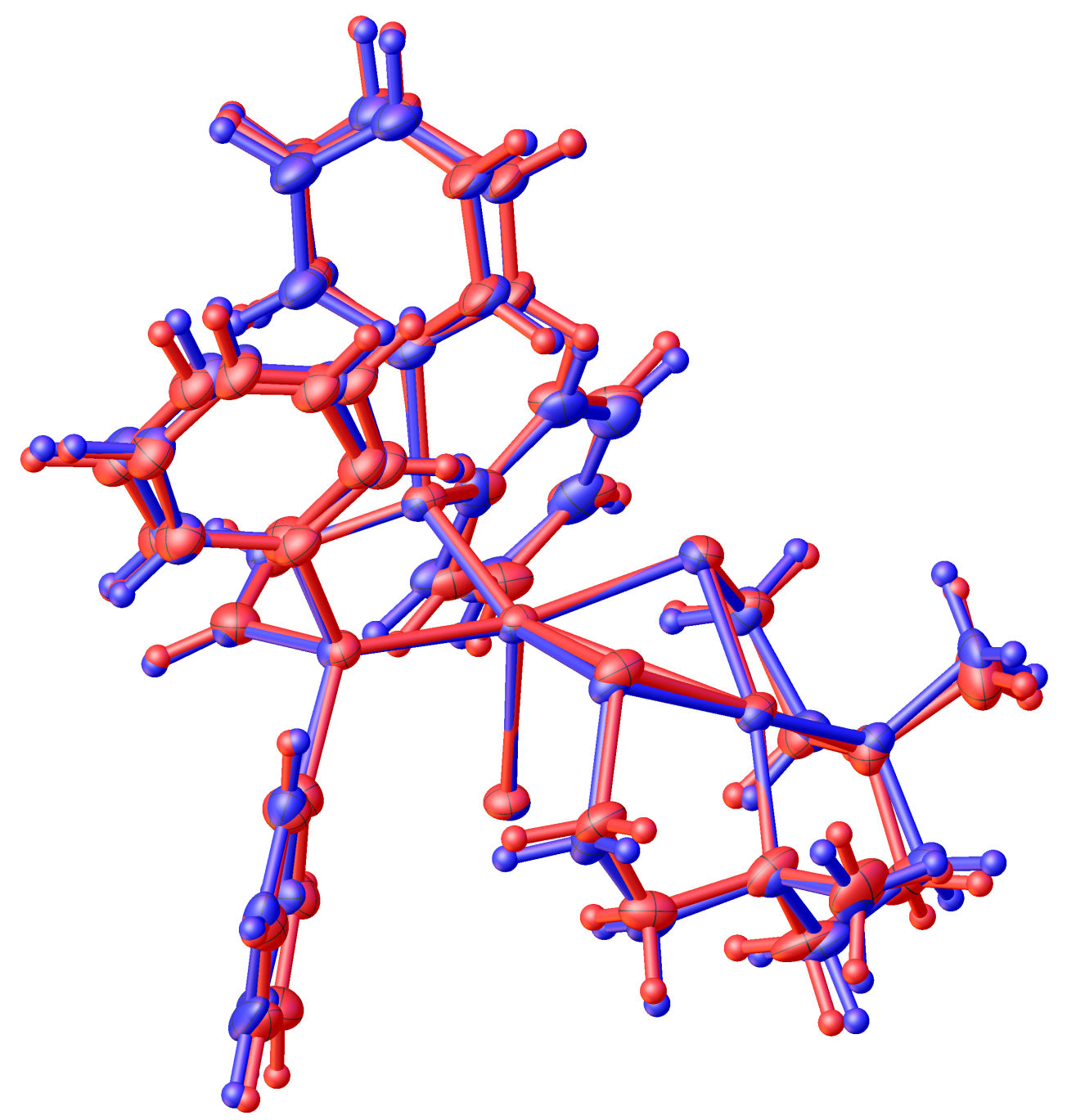

Figure S22. Overlay of the two cations in the asymmetric unit of $\{\mathrm{Ni}(\mathrm{Cl})($ dppv)[Ni(N2S2 $\left.\left.\left.{ }^{555}\right)\right]\right\} \mathrm{BF}_{4} \cdot \mathrm{CH}_{2} \mathrm{Cl}_{2}$. 
Table S1. Crystallographic refinement parameters of: SFLY's 4 (published ${ }^{1}$ ), rerefinement of SFLY's data but with Ni in place of Fe, SFLY's 5 (published ${ }^{1}$ ), rerefinement of SFLY's data but with $\mathrm{Ni}$ in place of $\mathrm{Fe}$.

\begin{tabular}{|c|c|c|c|c|}
\hline & 4 SFLY & 4 as $\mathrm{NiNi}$ & 5 SFLY & 5 as $\mathrm{NiNi}$ \\
\hline Sample & $\begin{array}{c}\left\{\mathrm{Fe}(\mathrm{Cl})(\mathrm{dppv})\left[\kappa^{2}-\right.\right. \\
\left.\left.\mathrm{NiN}_{2} \mathrm{~S}_{2}{ }^{555}\right]\right\} \mathrm{BF}_{4} \\
\mathrm{CH}_{2} \mathrm{Cl}_{2} \cdot \mathrm{H}_{2} \mathrm{O}\end{array}$ & $\begin{array}{c}\left\{\mathrm{Ni}(\mathrm{Cl})(\mathrm{dppv})\left[\kappa^{2}-\right.\right. \\
\left.\left.\mathrm{NiN}_{2} \mathrm{~S}_{2}{ }^{555}\right]\right\} \mathrm{BF}_{4} \\
\mathrm{CH}_{2} \mathrm{Cl}_{2} \cdot \mathrm{H}_{2} \mathrm{O}\end{array}$ & $\begin{array}{c}\left\{\mathrm{Fe}(\mathrm{dppv})\left[\kappa^{2-}\right.\right. \\
\left.\left.\mathrm{NiN}_{2} \mathrm{~S}_{2}{ }^{565}\right]\right\} \\
\quad\left(\mathrm{BF}_{4}\right)_{2}\end{array}$ & $\begin{array}{c}\left\{\mathrm{Ni}(\mathrm{dppv})\left[\kappa^{2}-\right.\right. \\
\left.\left.\mathrm{NiN}_{2} \mathrm{~S}_{2}{ }^{565}\right]\right\} \\
\left(\mathrm{BF}_{4}\right)_{2}\end{array}$ \\
\hline Formula Weight & 942.5 & 945.36 & 904.94 & 907.8 \\
\hline $\begin{array}{l}\text { Space Group } \\
\text { Unit cell }\end{array}$ & $P 2_{1} / n$ & $P 2_{1} / n$ & Fdd2 & Fdd2 \\
\hline $\mathrm{a}(\AA ̊)$ & $15.6516(4)$ & $15.6516(4)$ & $64.5574(16)$ & $64.5574(16)$ \\
\hline$b(\AA ̊)$ & $12.1445(3)$ & $12.1445(3)$ & $20.2967(7)$ & $20.2967(7)$ \\
\hline$c(\AA)$ & $21.9790(5)$ & $21.9790(5)$ & $11.8593(4)$ & $11.8593(4)$ \\
\hline$\alpha\left(^{\circ}\right)$ & 90 & 90 & 90 & 90 \\
\hline$\beta\left(^{\circ}\right)$ & $106.692(3)$ & $106.692(3)$ & 90 & 90 \\
\hline$\gamma\left({ }^{\circ}\right)$ & 90 & 90 & 90 & 90 \\
\hline Volume $\left(\AA^{3}\right)$ & $4001.77(18)$ & $4001.77(18)$ & 15539.3(8) & 15539.3(8) \\
\hline Z & 4 & 4 & 16 & 16 \\
\hline Density $\left(\mathrm{Mg} / \mathrm{m}^{3}\right.$ ) & 1.564 & 1.569 & 1.547 & 1.552 \\
\hline $\begin{array}{l}\text { Absorption } \\
\text { coefficient }\left(\mathrm{mm}^{-1}\right)\end{array}$ & 7.501 & 5.178 & 1.116 & 1.227 \\
\hline$F(000)$ & 1936 & 1944 & 7424 & 7456 \\
\hline $\begin{array}{l}\text { Data / restraints / } \\
\text { parameters }\end{array}$ & 7087 / 84 / 474 & $7087 / 84 / 474$ & $\begin{array}{c}6119 \text { / } 31 \text { / } \\
480\end{array}$ & $\begin{array}{c}6119 \text { / } 31 / \\
480\end{array}$ \\
\hline $\begin{array}{l}\text { Goodness-of-fit } \\
\text { on } F^{2}\end{array}$ & 1.043 & 1.05 & 1.047 & 1.038 \\
\hline $\begin{array}{l}\text { Final } R \text { indices } \\
{[I>2 \text { sigma }(I)]}\end{array}$ & $\begin{array}{c}R 1=0.0627 \\
w R 2=0.1633\end{array}$ & $\begin{array}{c}R 1=0.0611 \\
w R 2=0.1630\end{array}$ & $\begin{array}{c}R 1=0.0411 \\
W R 2=0.1072\end{array}$ & $\begin{array}{c}R 1=0.0392 \\
w R 2=0.1012\end{array}$ \\
\hline $\mathrm{R}$ indices (all data) & $\begin{array}{c}R 1=0.0768 \\
W R 2=0.1823\end{array}$ & $\begin{array}{c}R 1=0.0733 \\
w R 2=0.1778\end{array}$ & $\begin{array}{c}R 1=0.0432 \\
W R 2=0.1084\end{array}$ & $\begin{array}{c}R 1=0.0412 \\
w R 2=0.1023\end{array}$ \\
\hline $\begin{array}{l}\text { Largest diff. peak } \\
\text { and hole }\left(\mathrm{e} . \AA^{-3}\right)\end{array}$ & 1.446 and -1.133 & 1.374 and -1.149 & $\begin{array}{c}1.751 \text { and - } \\
0.681\end{array}$ & $\begin{array}{c}1.849 \text { and - } \\
0.677\end{array}$ \\
\hline $\begin{array}{l}\text { Absolute structure } \\
\text { parameter }\end{array}$ & $\mathrm{n} / \mathrm{a}$ & $\mathrm{n} / \mathrm{a}$ & $-0.031(5)$ & $0.008(5)$ \\
\hline
\end{tabular}


Table S2. Crystallographic refinement parameters of: SFLY's 7 (published ${ }^{1}$ ) and rerefinement of SFLY's data but with $\mathrm{Ni}$ in place of Fe.

\begin{tabular}{|c|c|c|}
\hline & 7 SFLY & 7 as $\mathrm{NiNi}$ \\
\hline Sample & $\begin{array}{l}\left\{\mathrm{Fe}(\mathrm{dppv}) \mid\left[\kappa^{2}-\right.\right. \\
\left.\left.\mathrm{NiN}_{2} \mathrm{~S}_{2}{ }^{555}\right]\right\} \mid+ \\
\quad \text { solvate }\end{array}$ & $\begin{array}{l}\left\{\mathrm{Ni}(\mathrm{dpp}) \mathrm{I}\left[\mathrm{\kappa}^{2}-\right.\right. \\
\left.\left.\mathrm{NiN}_{2} \mathrm{~S}_{2}{ }^{555}\right]\right\} \mathrm{I}+ \\
\quad \text { solvate }\end{array}$ \\
\hline Formula Weight & $971.1+$ solvate & $\begin{array}{c}973.96+ \\
\text { solvent }\end{array}$ \\
\hline Space Group & $P 2_{1} / n$ & $P 2{ }_{1} / n$ \\
\hline Unit cell & & \\
\hline$a(\AA)$ & $13.7085(5)$ & $13.7085(5)$ \\
\hline$b(\AA)$ & $13.6474(6)$ & $13.6474(6)$ \\
\hline$c(\AA)$ & $21.9742(9)$ & $21.9742(9)$ \\
\hline$\alpha\left(^{\circ}\right)$ & 90 & 90 \\
\hline$\beta\left(^{\circ}\right)$ & $99.643(4)$ & $99.643(4)$ \\
\hline$\gamma\left({ }^{\circ}\right)$ & 90 & 90 \\
\hline Volume $\left(\AA^{3}\right)$ & $4053.0(3)$ & $4053.0(3)$ \\
\hline Z & 4 & 4 \\
\hline Density $\left(\mathrm{Mg} / \mathrm{m}^{3}\right)$ & 1.591 & 1.596 \\
\hline $\begin{array}{l}\text { Absorption } \\
\text { coefficient }\left(\mathrm{mm}^{-1}\right)\end{array}$ & 2.552 & 2.659 \\
\hline$F(000)$ & 1920 & 1928 \\
\hline $\begin{array}{l}\text { Data / restraints / } \\
\text { parameters }\end{array}$ & 8377 / 3 / 399 & 8377 / 3 / 399 \\
\hline $\begin{array}{l}\text { Goodness-of-fit on } \\
\mathrm{F}^{2}\end{array}$ & 1.036 & 1.041 \\
\hline $\begin{array}{l}\text { Final R indices } \\
{[1>2 \text { sigma(I)] }}\end{array}$ & $\begin{array}{l}R 1=0.0460 \\
W R 2=0.1145\end{array}$ & $\begin{array}{c}R 1=0.0428 \\
W R 2=0.1059\end{array}$ \\
\hline $\mathrm{R}$ indices (all data) & $\begin{array}{c}R 1=0.0619, \\
w R 2=0.1275\end{array}$ & $\begin{array}{c}R 1=0.0581 \\
W R 2=0.1207\end{array}$ \\
\hline $\begin{array}{l}\text { Largest diff. peak } \\
\text { and hole }\left(e . \AA^{-3}\right)\end{array}$ & $\begin{array}{c}1.402 \text { and - } \\
0.844\end{array}$ & $\begin{array}{c}1.285 \text { and - } \\
0.667\end{array}$ \\
\hline $\begin{array}{l}\text { Absolute structure } \\
\text { parameter }\end{array}$ & $\mathrm{n} / \mathrm{a}$ & $\mathrm{n} / \mathrm{a}$ \\
\hline
\end{tabular}


Table S3. Crystallographic refinement parameters of: SFLY's 9 (published ${ }^{1}$ ) ; rerefinement of SFLY's data but with $\mathrm{Ni}$ in place of $\mathrm{Fe}$, and the Ni-Ni compound prepared in this work.

\begin{tabular}{l|c|c|c} 
& & & Sample prepared \\
without Fe
\end{tabular}




\section{Crystallographic refinements of SFLY's reported structures.}

Compounds 4, 5, 7, and 9 as reported by SFLY as Fe-Ni salts were re-refined as Ni-Ni salts. The original data were obtained from the $\mathrm{CSD}^{2}$ (OLIBAP (4), OLIBET (5), OLIBOD (7) and OLIBUJ (9) and the data and refined models were shredded from the cifs using SHREDCIF. ${ }^{3}$ All structures were re-refined using SHELXL ${ }^{2}$ in Olex2. ${ }^{4}$ The only changes to structures $\mathbf{4}$ and $\mathbf{5}$ was the replacement of $\mathrm{Ni}$ for the $\mathrm{Fe}$ atom. In addition to replacing $\mathrm{Ni}$ for the Fe atom in $\mathbf{7}$, all original restraints were removed that were placed on the original refinement to improve the displacement parameters for the atoms. Twenty-five low angle reflections were also omitted from the final refinement as they were likely blocked by the beam stop. In addition to replacing $\mathrm{Ni}$ for the $\mathrm{Fe}$ atom in Structure $\mathbf{9}$, additional displacement parameter restraints were imposed on the disorder in the $\mathrm{N}-\mathrm{CH}_{2}-\mathrm{CH}_{2}-\mathrm{N}$ segment of the $\left[\mathrm{\kappa}^{2}-\mathrm{NiN}_{2} \mathrm{~S}_{2}{ }^{555}\right]$ portion of the compound. This change did not significantly improve the overall fit, but did improve the refined displacement parameters of the disordered ligand.

(1) Song, L.-C.; Feng, L.; Lu, Y.; Yang, X.-Y. "Synthesis, Structures, and Reactivity of [NiFe]-H2ase Mimics Containing One Square-Planar N2S2 Ligand Bridged between Their Ni/Fe Centers through One or Two S Atoms" Organometallics 2021, 40, 508-519.

(2) Groom, C. R.; Bruno, I. J.; Lightfoot, M. P.; Ward, S. C. "The Cambridge Structural Database" Acta Cryst. 2016, B72, 171-179.

(3) Sheldrick. G. M. "Crystal structure refinement with SHELXL" Acta Cryst. 2015, C71, 3-8.

(4) Dolomanov, O.V.; Bourhis, L.J.; Gildea, R.J.; Howard, J.A.K.; Puschmann, H. "OLEX2: a complete structure solution, refinement and analysis program" J. Appl. Cryst. 2009, 42, 339-341. 